\title{
Perkembangan Bank Syariah Di Asia Tenggara: Sebuah Kajian Historis
}

\author{
Mohammad Ghozali, Muhammad Ulul Azmi \& Wahyu Nugroho \\ Program Pascasarjana Hukum Ekonomi Syariah, \\ Universitas Darussalam Gontor \\ E-mail: mohammadghozali@ unida.gontor.ac.id
}

\begin{abstract}
The development of Islamic Banking in Southeast Asia is growing rapidly. Statistical data shows that Southeast Asia has become one of the centers for the development of the global Islamic finance industry. Literally, Indonesia and Malaysia is two countries in the region that have become dynamos for the development of the Islamic banking industry in ASEAN countries, this condition has encouraged other countries to be discussed in the development of the Islamic banking industry. The method of this paper is historical approach, which documentary methods in data collection techniques by analyzing documents that are relevant to the research topic. The conclusion of this study is that significant developments still occur in two countries, namely Malaysia and Indonesia, whereas in some countries such as Thailand, Singapore and the Philippines the development of Islamic banking is still minimal.
\end{abstract}

Kata Kunci: Islamic Bank, Southeast Asia, Islamic Financial Institutions.

\section{ABSTRAK}

Pertumbuhan perbankan Islam di Asia Tenggara berkembang sangat pesat, data statistik menunjukkan bahwa Asia Tenggara telah menjadi salah satu pusat pengembangan industri keuangan Islam secara global. Dalam sejarah tercatat bahwa Indonesia dan Malaysia sebagai negara di kawasan ini yang menjadi dinamo pengembangan industri perbankan syariah di antara negara-negara anggota ASEAN, kondisi ini mendorong negara-negara Asia Tenggara lainnya untuk berpartisipasi dalam pengembangan industri perbankan Islam. Penelitian ini bertujuan untuk membahas secara mendalam terkait perkembangan perbankan syariah di negara-Negara Asia Tenggara. Pendekatan yang digunakan adalah historis dengan metode dokumenter dalam teknik pengumpulan data, yaitu dengan melakukan analisis terhadap dokumen-dokumen 
yang relevan dengan topik penelitian. Kesimpulan dari penelitian ini adalah bahwa perkembangan yang signifikan masih terjadi pada dua Negara yaitu Malaysia dan Indonesia, sebaliknya di beberapa Negara seperti Thailand, Singapura dan Filipina perkembangan perbankan syariah masih minim.

Kata Kunci: Bank Syariah, Asia Tenggara, Lembaga Keuangan Syariah.

\section{Pendahuluan}

Bank syariah merupakan lembaga keuangan yang operasional dan produknya dikembangkan berlandaskan Al-Qur'an dan hadist, khususnya yang menyangkut tata cara bermuamalat secara islam (Antonio \& Perwataatmaja, 2001; Umam, 2013: 15). Pertumbuhan perbankan syariah di dunia diawali dengan berdirinya Mit Gamr Bank di Mesir pada tahun 1963. Selanjutnya Dubai Islamic Bank menjadi bank komersial pertama yang membuka layanan syariah pada tahun 1975. Berdasarkan wilayah ekonominya, perbankan syariah pertama di Asia Tenggara adalah Bank Islam Malaysia Berhad yang berdiri di Malaysia pada tahun 1983 (Ketell, 2011: 24).

Pertumbuhan industri keuangan syariah yang pesat dan stabil juga menjadikan Asia Tenggara sebagai bagian penting dalam keuangan Islam global. Negaranegara di Asean memiliki variasi yang beragam dalam pengembangan perbankan Syariah. Malaysia merupakan Negara yang paling cepat dalam pengembangan perbankan syariah diantara Negara-negara di Asean, lalu Indonesia juga gencar dalam usahanya mengembangkan perbankan syariah, walaupun perkembangannya lambat jika dibandingkan dengan Malaysia, karena pendekatan yang digunakan berbeda. Pendekatan yang digunakan di Malaysia adalah pendekatan (state driven), sedangkan perbankan syariah di Indonesia lebih banyak digerakkan oleh masyarakat (market driven).

Selain di kedua Negara tersebut, Brunei Darussalam juga intens dalam mengembangkan industri perbankan syariah. Selanjutnya Singapura yang merupakan Negara minoritas muslim juga berambisi untuk mengembangkan industri ini. Dan juga ambisi ini diikuti Negara-negara minoritas muslim lainnya seperti Filipina, dan Thailand dengan mengakomodir keberadaan bank syariah di negaranya. Artikel ini bertujuan untuk mengetahui bagaimana perkembangan ekonomi syariah di Asia Tenggara dilihat dari pertumbuhan dan perkembangan perbankan syariah.

\section{Perkembangan Perbankan Syariah di Indonesia}

Perkembangan bank syariah di Indonesia tidak bisa lepas dari sejarah terbentuknya Islamic Development Bank (IDB) yang didirikan oleh OKI sebagai Organisasi Konfrensi Islam pada tahun 1975 yang memberikan perkembangan berkaitan dengan perbankan dan keuangan Islam. IDB juga membantu dalam mendirikan bank-bank Islam di berbagai Negara serta membangun institusi untuk penelitian, penulisan dan pelatihan di bidang perbankan dan keuangan (Nugroho, 2015: 2). 
Ikhtiar yang lebih khusus mengenai pendirian Bank Islam di Indonesia baru dilakukan tahun 1990. Pada tanggal 18-20 Agustus tahun tersebut, Majelis Ulama Indonesia (MUI) menyelenggarakan lokakarya bunga bank dan perbankan di Cisarua, Bogor, Jawa Barat. Hasil lokakarya tersebut kemudian dibahas lebih mendalam pada Musyawarah Nasional IV MUI di Jakarta 22-25 Agustus 1990, yang menghasilkan amanat bagi pembentukan kelompok kerja pendirian bank Islam di Indonesia. Berbeda dengan tujuan bank konvensional yang hanya mencanangkan pencapaian keuntungan yang setinggi-tingginya (profit maximization). Perbankan Syariah bertujuan untuk menggalakkan, memelihara serta mengembangkan jasa serta produk perbankan yang berdasarkan syariah (Tim Pengembangan Perbankan Syariah, 2001: 23).

Bank syariah di Indonesia sendiri sebenarnya telah mendapatkan dasar legitimasi yang kuat dengan ketentuan deregulasi sektor perbankan pada tahun 1983. Hal ini karena sejak saat itu diberikan keleluasaan penentuan tingkat suku bunga hingga nol persen (peniadaan bunga sekaligus). Akan tetapi kesempatan ini belum bisa dimanfaatkan karena tidak diperkenankan untuk membuka lembaga baru. Kondisi ini berlangsung hingga pemerintah mengeluarkan Paket Kebijakan Oktober (Pakto) 1988 yang memperkenankan berdirinya bank-bank baru (Umam, 2013: 22).

Selanjutnya posisi perbankan syariah semakin kokoh setelah disahkan UU Perbankan Nomor 7 Tahun 1992, dimana bank diberikan kebebasan untuk menentukan jenis imbalan yang akan diambil dari nasabahnya, baik bunga ataupun keuntungan bagi hasil. Dengan terbitnya peraturan tersebut tentang bank bagi hasil yang secara tegas memberikan batasan bahwa bank bagi hasil tidak boleh melakukan kegiatan usaha yang tidak berdasarkan prinsip bagi hasil (bunga), sebaliknya bank yang kegiatan usahanya tidak berdasarkan prinsip bagi hasil tidak diperkenankan melakukan kegiatan usaha berdasarkan prinsip bagi hasil, maka jalan bagi perkembangan perbankan syariah semakin luas (Muhammad, 2004: 21). Dengan demikian kegiatan operasional perbankan di Indonesia didasarkan pada dua sistem yaitu: sistem bunga dan sistem syariah, sedangkan bank umum konvensional dapat menganut dual banking system.

Bank Muamalat Indonesia (BMI) merupakan bank syariah pertama yang berdiri pada tahun 1991, berdirinya bank ini diprakarsai oleh Majelis Ulama Indonesia (MUI) dan pemerintah serta dukungan dari Ikatan Cendekiawan Muslim Indonesia (ICMI) dan beberapa pengusaha muslim. Akte pendiriannya ditandatangani pada tanggal 1 November 1991. Pada saat itu terkumpul komitmen pembelian saham sebanyak Rp84 miliar (Antonio, 2001: 25).

Menurut Wirdyaningsih dkk (2005: 3), bahwa hingga terbitnya undangundang Nomor 10 tahun 1998, Indonesia telah melewati dua tahapan pembinaan, yaitu "tahapan perkenalan" (introduction) yang ditandai dengan diberlakukanya undang-undang Nomor 7 tahun 1992, dan tahapan pengakuan (recognition) yang ditandai diberlakukanya UU Nomor 10 tahun 1998. Tahapan berikutnya adalah 
"tahapan pemurnian" (purification) yang nanti akan ditandai dengan diberlakukanya Undang-undang yang secara khusus mengatur perbankan syariah.

Undang-undang yang dimaksud akhirnya disahkan pada 17 Juni 2008, yang mana di dalamnya diatur mengenai jenis usaha, ketentuan pelaksanaan syariah, kelayakan usaha, penyaluran dana dan larangan bagi bank syariah maupun UUS yang merupakan bagian dari bank umum kovensionai. Dan sebagai UU yang khusus mengatur perbankan syariah, dalam UU ini diatur mengenai masalah kepatuhan syariah (syariah compliance) yang kewenangannya berada pada MUI yang direpresantasikan melalui Dewan Pengawas Syariah (DPS). Kemudian, harus dibentuk pada masing-masing bank syariah dan Unit Usaha Syariah. Untuk menindaklanjuti implementasi fatwa yang dikeluarkan MUI ke dalam Perturan Bank Indonesia (PBI), maka dibentuk komite Komite Perbankan Syariah, yang keanggotaannya terdiri atas perwakilan dari Bank Indonesia, Departemen Agama, dan unsur masyarakat yang komposisinya berimbang (Prasetyo, 2010: 29).

Keberadaan UU Nomor 21 tahun 2008 tentang perbankan syariah melegalkan keberadaan perbankan syariah di Indonesia dengan segala macam karakteristiknya. Keberadaan UU ini juga menjadi pijakan yang kokoh bagi Peraturan Bank Indonesia yang mengatur secara teknis tentang perbankan syariah di Indonesia. Di samping itu, banyak kalangan berpendapat bahwa keberadaan UU perbankan syariah akan menjadi titik tolak masuknya investasiyang menjadikan perbankan syariah sebagai tuan rumah di negeri sendiri (Prasetyo, 2010: 71).

\section{Perkembangan Perbankan Syariah di Malaysia}

Era perbankan syariah di Malaysia bisa ditelusuri kembali ke tahun 1963 yang mana pada saat itu pemerintah membentuk lembaga Tabung Haji. Lembaga ini dibentuk untuk menjadi sarana investasi tabungan masyarakat Malaysia dengan instrument bebas bunga terkhusus untuk mereka yang ingin menuanaikan ibadah haji.Lalu selanjutnya dikenal konsep perbankan Islam di Malaysia pada awal tahun 80-an dengan tujuan yang mulia yaitu untuk membantu umat Islam dengan memberikan sistem yang lebih baik dibandingkan Tabung Haji (Sjahdeini, 2014: 74).

Awal 1980-an adalah awal langkah diperkenalkannya perbankan syariah di Malaysia atas inisiatif Pedana Menteri Mahathir Muhammad, yaitu ketika Malaysia secara resmi memperkenalkan Undang-undang Perbankan Syariah 1983 (IBA 1983), dan UU Takaful 1984. Kemudian Bank Syariah yang menerapkan konsep syariah secara lengkap juga didirikan sebagai perusahaan umum pada tahun 1983. Bank Islam Berhad adalah bank pertama yang didirikan pada 1 Maret 1983 (Basalamah \& Rizal, 2018: 138). yang sepenuhnya menawarkan produk dan layanan perbankan syariah. Ini akan tetap untuk waktu 10 tahun (Thani, et.al, 2010: 103). Pada periode inilah perbankan syariah di Malaysia berada pada tahap awal dan tahap percobaan dan partisipasi dari non-muslim pada perbankan syariah 
sangat minim. Beberapa tahun kemudian, Bank Muamalat Malaysia Berhard berdiri yaitu pada tahun 1999 (Basalamah \& Rizal, 2018: 138).

UU IBA 1983 telah memberikan kewenangan besar kepada Bank Negara Malaysia (BNM) untuk melakukan supervisi dan regulasi bank syariah. Adapun isi IBA 1983 mengatur tentang perizinan dan peraturaan mengenai pengelolaan dan operasional bisnis perbankan syariah. Selain itu, UU tadi juga mangatur tentang syarat-syarat keuangan dan tugas bank syariah, kepemilikan serts kontrol bank syariah, batasan-batasan bank syariah dan kekuatan supervise dan control terhadap bank syariah (Islamic Bank Act (IBA), 1983).

Selanjutnya Bank Negara Malaysia (BNM) memperkenalkan suatu bentuk skema "Skema Perbankan tanpa Bunga" (Interest Free Banking Scheme). Dalam kebijakan yang sering disebut sebagai "Islamic Window" yang mana berdampak pada diizinkannya bank komersial, bank dagang maupun perusahaan keuangan untuk menawarkan produk dan layanan perbankan syariah. Hal ini sangat sukses karena lebih banyak masyarakat muslim maupun non muslim yang berpartisipasi dalam perbankan syariah (Thani, et.al, 2010: 245). Yang selanjutnya menghilangkan persepsi bahwa perbankan Islam hanya untuk masyarakat beragama Islam. Diantara bank komersial yang menerapkan Islamic Window adalah HSBC Bank Malaysia Berhard, OCBC Bank Malaysia Berhard, dan Standard Chartered Bank Malaysia Berhard.

Selain IBA 1983 dan BAFIA 1989, Central Bank Act (CBA) 1958 yang selanjutnya pada tahun 2009 diterbitkan Central Bank Act yang baru sebagai pengganti CBA 1958 juga sangat berkontribusi dalam pengembangan perbankan syariah di Malaysia terkhusus perihal regulasi, supervisi dan monitoring pelaksanaan bank syariah. Adanya perubahan atas CBA 1958 ini juga usaha dalam penyempurnaan dan pengembangan pasal sesuai dengan kondisi perkembangan perbankan dan keuangan (Rama, 2015: 116).

Lebih lanjut, pengesahan Bank Central Act tahun 2009 juga memberikan kejelasan yang lebih besar mengenai peran Dewan Penasehat Shariah Nasional sebagai otoritas tertinggi dan pusat untuk segala masalah dan pertanyaan perbankan syariah dan lembaga keuangan syariah dan juga pengadilan hukum. Dan berdasarkan BCA 2009, keputusan apapun yang dibuat oleh Dewan Penasehat Syariah Nasional akan mengikat lembaga keuangan syariah, pengadilan dan arbiter (Kunhibava, 2012: 4).

Perkembangan yang lebih baru oleh Bank Central Malaysia yaitu melayani perbaikan tata kelola (kerangka kerja) syariah lembaga keuangan syariah (Islamic Financial Institution) di Malaysia. Di bawah kerangka ini merupakan sebuah tugas dan tanggug jawab IFI dalam membangun tata kelola syariah yang sehat dan kuat. Ini bertujuan untuk meningkatkan peran Dewan Direksi, Dewan Penasehat Syariah, dan Manajemen dalam kaitannya mengenai permasalahan syariah, termasuk meningkatkan organ-oragan kunci yang relevan yang mepunyai 
tanggung jawab untuk melaksanakan fungsi-fungsi kepatuhan dan penelitian syariah (http://www.bnm.gov.my)

Selain itu, salah satu momentum penting dalam upaya menguatkan sekaligus harmonisasi aspek regulasi sistem keuangan syariah di Malaysia adalah dikeluarkannya undang-undang baru yang bernama Islamic Financial Services (IFSA) Act pada tahun 2013 dan Financial Services Act di tahun yang sama. Kedua UU ini menggantikan BAFIA 1989, IBA 1983, dan Takaful Act 1984. Aturan ini menempatkan pemberian mandat kepada BNM untuk memberlakukan kebijakan yang fair, bertanggungjawab dan professional kepada para pelaku lembaga keuangan (Rama, 2015: 116).

Setelah 10 tahun anak perusahaan yang berlandaskan Islam mulai muncul seiring dengan diperkenalkannya RHB Islamic Berhad, dan Hong Leong Islamic Berhad yang diluncurkan pada tahun 2005. Anak perusahaan ini didirikan oleh oleh bank komersial domestik dan dilisensikan sebagai bank syariah dibawah IBA 1983 (Sjahdeini, 2014: 79). Dalam periode yang sama bank-bank syariah asing yang ada di Malaysia diberi izin untuk melakukan praktik perbankan syariah di Malaysia. Bank-bank Islam asing ini termasuk di dalamnya, Kuwait Finance House, Bank Al-Rajhi dan Asian Finance House (Thani, et.al, 2010: 101-102). Saat ini, terdapat lebih dari 17 bank syariah lokal dan 5 bank Islam Internasional yang telah beroperasi di Malaysia. Sementara terdapat 15 bank yang berpartisipasi dalam mengembangkan skema perbankan syariah.

\section{Perkembangan Perbankan Syariah di Brunei Darussalam}

Brunei Darussalam adalah Negara dengan sistem kesultanan Islam independen yang terletak di pantai utara pulau Kalimantan. Gaya hidup di Brunei sangat kental dengan mendasarkan pada agama. Negara ini bersih dari club malam, tidak memperbolehkan konsumsi alcohol di restoran dan tempat umum, dan kehalalan makanan dijamin oleh departemen pemerintahan yang berwenang. Dilihat dari gaya kehidupan yang diterapkan seperti konsep utama Melayu Islam Beraja (MIB) atau Monarki Islam melayu akan dipertahankan dan ditegakkan oleh kesultanan. Oleh karena itu tidak heran bahwa sultan Brunei memutuskan untuk meluncurkan bank Islam pertama di Brunei. Bank ini memberikan warga Brunei langkah besar menuju kehidupan yang berlandaskan syariah. Bank Islam tidak hanya menghapus elemen riba atau interest tetapi juga memberikan fondasi sosioekonomi yang lebih baik untuk Negara (Latiffin Ali\& Ahmad,(n.d): 277-278).

Bank pertama di Brunei berdiri pada tahun 1935 dengan nama Post Office Saving Bank yang telah berdiri sebelum masa kolonialisasi Inggris di Brunei. Selanjutnya pada masa kolonialisasi Inggris turut didirikan pula bank lain seperti Bank Hongkong \& Shanghai pada sekitar tahun 1940-an. Bank-bank ini didukung sepenuhnya oleh Inggris dengan menggunakan sistem perbankan konvensional yang didasarkan pada hukum Inggris (British Law). Beberapa bank yang selanjutnya berdiri adalah Malaya Banking (1960), United Malayan Banking Corporation (1963), National Bank of Brunei (1964), Citibank (1971), Islamic 
Developmant Bank (1980), Baiduri Bank (1992), Tabung Amanah Islamic Brunei (1992), dan Development Bank of Brunei (1995). Dan pada pertengahan tahun 1980-an, Bank National of Brunei menggabungkan diri dengan Island Development Bank (IDB) dengan nama International Bank of Brunei. Bank ini merupakan satu-satunya bank local yang berdiri di Brunei pada saat itu (Ebrahim, 2001: 327)

Sultan Brunei selanjutnya memulai pembentukan bank Islam di Brunei. Dalam pidato kerajaan di Pertemuan Dewan Agama Islam yang diselenggarakan pada bulan September 1990, ia menekankan bahwa pendirian bank Islam adalah penting karena ini kewajiban 'fard kifayah' untuk setiap negara Muslim dan Negara Brunei Darussalam. Perintah ini memprakarsai awal dari lebih banyak pertemuan yang diselenggarakan oleh Dewan Agama Islam yang menghasilkan pembentukan komite yang dikenal sebagai Pembentukan Komite Bank Islam (Latiffin Ali \& Ahmad, (n.d): 277-278). Pada tahun 1993, Bank Internasional Brunei menggati nama menjadi Bank Islam Brunei untuk mengelola urusan keuangan masyarakat sesuai dengan cita-cita luhur Islam.

Bank-bank di Brunei Darussalam dipantau oleh Undang-Undang Perbankan dan Keuangan dan Undang-undang Perusahaan melalui Departemen Keuangan. Tidak ada bank nasional di Brunei tetapi tugas pemantauan berada di bawah yurisdiksi Moneter Keuangan melalui Dewan Mata Uang Brunei, Departemen Layanan Keuangan dan Badan Investasi Brunei. Dari semua bank Brunei, hanya Bank Islam Brunei (IBB) dan Tabung Amanah Islam Brunei (Islamic Trust Fund of Brunei) yang menawarkan layanan perbankan Islam, sementara yang lain menawarkan jasa keuangan berdasarkan praktik perbankan konvensional (Mohammad, et.al, 2013: 7).

Komitmen pertama Brunei yang signifikan untuk mengembangkan sistem Islam yang lengkap dimulai pada bulan September 1992, hal ini dinyatakan dengan pembukaan resmi Tabung Amanah Islam Brunei (TAIB) yang menggantikan International Bank Of Brunei (IBB) (Sjahdeini, 2014:83)

Islamic Development Bank Berhad (IDBB) pada awalnya didirikan sebagai bank konvensional pada Maret 1995, kemudian dikenal sebagai Bank Pembangunan Brunei (DBB), sebuah lembaga perbankan yang sepenuhnya milik pemerintah. Pada tanggal 4 April 2000, Sultan menginstruksikan bank untuk beroperasi sesuai prinsip-prinsip Islam (Latiffin Ali\& Ahmad,(n.d): 282).

Hingga kini, terdapat tiga belas tahun sejak lembaga keuangan Islam pertama didirikan di Brunei. Selama periode ini dapat disaksikan pertumbuhan yang pesat sebagaimana terbukti dengan jumlah cabang yang telah dibuka di seluruh penjuru Brunei (Latiffin Ali\& Ahmad,(n.d): 284)

\section{Perkembangan Perbankan Syariah di Singapura}

Singapura adalah Negara dengan sistem ekonomi campuran antara kapitalis dan sosialis, dan untuk memperluas jaringan kerjasama ekonomi Singapura 
tertarik dengan Foreign Direct Invesment (FDI), Sovereign Wealth Fund (SWF), dan Petrodolar. Hal ini lah yang kemudian menjadi faktor yang menyebabkan keseriusan yang lebih bagi pemerintah Singapura untuk memantau perkembangan sistem ekonomi Islam (Mardiah, 2016: 4-5).

Dukungan terhadap sistem perbankan dan keuangan syariah di Singapura datang dari Menteri Senior Goh Chok Tong pada November 2004. Ia berjanji untuk meningkatkan status Singapura sebagai Pusat Jasa Keuangan Syariah (center for Islamic Financial Services). Selanjutnya pada bulan Maret 2005, Perdana Menteri Singapura mengemumkan rencana perubahan undang-undang (amandemen) untuk mempermudah setiap bank untuk menawarkan produk dan jasa keuangan syariah. Pemerintah juga akan merivisi peraturan yang menghambat suatu bank untuk menawarkan produk syariah (Mohammad, et.al., (n.d): 10)

beberapa langkah yang dilakukan untuk mendukung adalah dengan memasukkan penghapusan pengenaan bea materai ganda transaksi-transaksi syariah yang melibatkan real estate dan juga akan terjadi pada penyelesaian pembayaran obligasi syariah yang perlakuannya sama dengan pajak yang diberikan untuk bunga yang timbul dari keuangan konvensional. Selain itu, pemerintah telah memulai serangkaian penandatanganan perjanjian perdagangan bebas dengan sejumlah Negara timur tengah dan Negara-negara teluk (Venardoz, 2005: 216).

Secara umum kerangka regulasi yang dikembangkan di Singapura terkait dengan industri perbankan dan keuangan syariah adalah memperlakukan secara sama dengan industri perbankan dan keuangan secara umum. Kerangka regulasi yang bersifat fleksibel ini disebabkan jumlah penduduk muslim dan perbankan syariah yang belum terlalu dominan, semua aktivitas bisnis perbankan di Singapura, baik konvensional maupun syariah, diatur oleh undang-undang perbankan (Banking Act) di bawah pengawasan Monetary Authority of Singapore (MAS). Seiring dengan perkembangan sistem keuangan syariah di Singapura maka dibutuhkan regulasi yang mengaturnya selain dari undang-undang yang sudah ada. Pada tahun 2008, MAS menerbitkan sebuah garis perunjuk (guidlines) dengan nama Guidelines on the Application of Banking Regulation to Islamic Banking .Guidelines ini bertujuan untuk menyediakan petunjuk bagi bank tentang peraturan bank syariah di Singapura, terutama tentang kerangka petunjuk bagi lembaga keuangan yang berkeinginan untuk membuka produk dan jasa keuangan syariah (Sjahdeini, 2014:74)

Sistem ekonomi Islam terbukti cukup berhasil di terapkan oleh Singapura, hal ini dibuktikan dengan didirikannya Islamic Bank of Asia pada tahun 2007 (Sjahdeini, 2014:74). Selanjutnya perbankan syariah memang semakin berkembang, hal ini ditandai dengan kemunculan bank syariah internasional maupun bank konvensional yang mendirikan cabang khusus syariah maupun layanan perbankan syariah seperti bank DBS, Maybank, HSBC Amanah, OCBC 
Bank dan Noor Islamic Bank (Mardiah, (n.d): 6). Lembaga keuangan syariah lainnya yang telah membuka kantor di Singapura adalah Arcapita dan Al-Salam Bank-Bahrain.

\section{Perkembangan Perbankan Syariah di Filipina}

Filipina adalah Negara yang tergabung didalam organisasi ASEAN dengan mayoritas penduduknya adalah Kristen, bahkan jumlahnya lebih dari 80\%, sementara jumlah umat Islam hanya mewakili $8.5 \%$ dari total jumlah populasi penduduk disana yang jumlahnya sekitar 6 juta orang. Muslim Filipina dikenal dengan sebutan Moros, atau hanya disebut moor ini terjadi ketika Filipina berada dibawah pendudukan Spanyol pada tahun 1565. Dan pada 1898, Spanyol menyerahkan Filipina ke Amerika Serikat dibawah perjanjian Paris. Pemerintah Filipina sedang mempertimbangkan kemungkinan pengenalan bank-bank yang beroperasi di bawah prinsip-prinsip Islam untuk menyediakan layanan perbankan bagi seluruh masyarakat muslim khususnya yang tinggal di bagian Mindanau (Rama, 2015: 122)

Bank Islam di Filipina diatur oleh undang-undang khusus (bukan hukum perbankan umum) sebagaimana diatur dalam pasal 71 Undang-undang Republik No. 8791 (undang-undang yang memberikan peraturan organisasi dan operasi bank, kuasi bank, Entitas Trust dan keperluan lain) (Ibrahim, Omar \& Hamdan, 2018: 146). Bank Islam pertama di Filipina adalah Bank Amanah Filipina (PAB) didirikN pada tanggal 2 Agustus 1973 sebagai lembaga pemerintah khusus dibawah presiden Filipina Ferdinand Marcos dengan modal yang diberikan sebesar 100 juta Peso. Perwujudan PAB adalah tanggapan kerajaan yang terjadi karena pemberontakan oleh Muslim di Filipina selatan (Mindanau) (http://documents.worldbank.org).

Pada tahun 1974, AAIIBP diarahkan untuk menerapkan model perbankan dan pembiayaan Islam yang menngunakan prinsi "tanpa bunga" dan mekanisme kemitraan.Kemudian pada tahun 1990, PAB berubah bank syariah yang universal berdasarkan penandatanganan Republic Act No. 6848 yang biasa disebut Chartered of Al-Amanah Islamic Invesment Bank of The Philippines (AAIIBP). Selanjutnya AAIIBP berganti nama menjadi AIB, Mandat AIB adalah untuk mempromosikan dan mempercepat pembangunan sosial-ekonomi wilayah otonomi Muslim Mindanau melalui sistem perbankan, pembiayaan, dan partisipasi pada pertanian, perdagangan dan industri berdasarkan konsep perbankan syariah (http://www.amanahbank.gov.ph). Pada tahun 1989 AAIIBP kembali disewa dan dikapitalisasikan kembali berdasarkan Undang-undang Republik No. 6848, dengan modal 1 miliar peso. Pemerintah Filipina berusaha untuk memprivatisasi AIB pada tahun 2000 setelah mengalami kerugian pada pertengahan tahun 1990-an (Ibrahim, Omar\&Hamdan, 2018: 147).

Bagaimanapun Bank Islam ini tidak beroperasi penuh sebagai bank syariah yang mana disaat yang bersamaan masih mempraktekkan kepentingan sistem 
perbankan. Mereka juga memiliki pertimbangan bahwa perbankan Islam dalam preposisi perbankan yang sangat beresiko (Mohammad, et.al, 2013: 6).

\section{Perkembangan Perbankan Syariah di Thailand}

Keuangan syariah telah hadir di Thailand sejak tahun 1984 dalam bentuk tabungan koperasi dengan nama Pattani Saving Cooperative dengan tujuan untuk mengumpulkan dana-dana dari masyarakat khususnya yang tinggal di bagian selatan Thailand. Koperasi ini berdiri berdasarkan Undang-undang koperasi (Corporative Act), Thailand Muamalat Law 1968 dalam kategori Tabungan Koperasi dan dibawah pengawasan Lembaga Islam (Islamic Council) provinsi Pattani. Selanjutnya pada tahun 2004, terdapat 4 koperasi tabungan syariah berdiri di wilayah muslim tersebut, yaitu koperasi Tabungan Ibnu Affan, Koperasi Tabungan As-Siddiq, Koperasi Tabungan Saqaffah dan Koperasi Tabungan AlIslamiah (Rama, 2015: 124).

Pada tahun 2001, Khrung Thai Bank merupakan bank pertama yang membuka cabang Syariah. Bank ini berhasil menumbuhkan satu sistem perbankan Syariah yang dinamakan Krung Thai Syariah (syariah banking service) pada daerah yang berpenduduk muslim. Adapun beberapa produk yang ditawarkan adalah Simpanan atau tabungan, pembiayaan dan pinjaman yang berbentuk Murobahah, Mudhorobah, Bae' Bit Tsaman dan juga pembiayaan tabung haji dan umroh.Setelah berjayanya perbankan Islam pada Bank Krung Thai ini, dan akhirnya berpindah menjadi Bank Islam Thailand pada November 2005 (Hasan, 2006).

Setelah banyaknya bank pemerintah yang menawarkan produk keuangan syariah (Islamic window), muncul aspirasi untuk mendirikan sebuah bank yang sepenuhnya beroperasi sesuai syariah (full fledged Islamic bank) dan juga legal berdasarkan hukum Thailand. Sebagai respon, pemerintah meminta Menteri Keuangan Thailand untuk menyusun draf undang-undang tentang perbankan syariah yang akan diusulkan ke kabinet pada bulan Oktober 2002. Hasilnya, pada tahun 2002, parlemen Thailand mengesahkan undang-undang perbankan syariah dengan nama "The Islamic Bank of Thailand Act". UU ini menjadi dasar hukum berdirinya bank Islam pertama dengan nama Bank Islam Thailand (Islamic Bank of Thailand) (Sjahdeini, 2014: 94).

Bank Islam pertama ini dikontrol langsung oleh Kementerian Keuangan Thailand. Bank Islam Thailand ini mendapatkan dana dari pemerintah Thailand sebesar 1 miliar Bath berpusa di Klongton. Bank ini terus mengalami ekspansi cabang khususnya di Bangkok dan provinsi bagian selatan dan diakhir tahun 2005 bank ini telah memiliki 9 kantor cabang (http://www.ibank.co.th/2010/en). Ekspansi bisnis bank Islam Thailand terus dilakukan melalui akuisisi layanan perbankan syariah bank Krung Thai pada bulan November 2005. Saat ini, Bank Islam Thaland (IBank) sebagai bank milik pemerintah telah memiliki 130 kantor cabang yang tersebar di seluruh wilayah Thailand (Rama, 2015: 125). 


\section{Kesimpulan}

Asia Tenggara dengan sejumlah Negara yang mayoritas penduduknya beragama Islam memang menjadi perhatian internasional mengenai kaitannya dengan perkembangan keuangan Islam. Kemampuan industri keuangan Islam di wilayah ini dalam menghadapi krisis mata uang Asia pada akhir 1990-an dan krisis keuangan global ini setidaknya memunculkan pengakuan akan pentingnya posisi wilayah ini dalam percaturan industri yang berkembang ini. Pertumbuhan yang pesat dan stabil juga menjadikan Asia Tenggara sebagai bagian penting dalam keuangan Islam global.

Negara di Kawasan Asia Tenggara yang telah mengoperasikan Perbankan syariah adalah Indonesia, Malaysia, Brunei Darussalam, Thailand, Philipina dan Singapura. Walaupun fase yang dialami berbeda-beda, pertumbuhan dan perkembangan perbankan syariah sangat menggembirakan dan cukup menjanjikan. Secara global, perbankan syariah di Asia Tenggara menduduki peringkat kedua di dunia dalam hal asset terbesarnya. Dan kedudukan perbankan syariah di Asia Tenggara sangat diperhitungkan di seluruh dunia.

Tantangan yang terbesar yang akan dihadapi oleh Negara-negara Asia Tenggara dalam mengembangkan sistem keuangan syariah yang terintegrasi yaitu adanya kesenjangan pada kualitas perkembangan keuangan syariah pada setiap Negara-negara yang menerapkannya. Dan demi membangun kawasan keuangan berbasis syariah yang kuat dan terintegrasi maka diperlukan adanya kerjasama diantara pihak-pihak yang terkait. Dan yang menjadi syarat terpenting adanya integrasi keuangan syariah adalah terjadinya harmonisasi regulasi diantara Negara yang bersangkutan.

\section{Daftar Pustaka}

Basalamah, Muhammad Ridwan, Rizal, Muhammad, (2018), Perbankan Syariah, Malang: Empatdua Media.

Ebrahim, M. Shahid, (2001), Islamic Banking in Brunei Darussalam, International Journal of Social Economics, Vol.28 No.4.

Hasan, Arphandee, (2006), "Pelaksanaan Mudharabah di Krung Thai Bank Public Company Limited, Wilayah Yala, Thailand: Analisa menurut Perspektif Islam", (Disertasi Sarjana Syariah, Jabatan Fiqh dan Ushul, Bagian Pengajian Syariah, Akademi Pengajian Islam, Universiti Malaya.

Ibrahim, Hasmiene Diocolano, et.al, (2018), Critical Financial Analysis of Islamic Bank in the Philippines: Case Study of Amanah Islamic Bank, GJAT, January.

Institut Bankir Indonesia (2001), Konsep, Produk dan Implementasi Operasional Bank Syariah, Jakarta: Penerbit Djambatan.

Islamic Bank Act (IBA), 1983 
Ketell, Brian, (2011), The Islamic Banking and Finance Workbook, United Kingdom: John Wiley \& Sons.

Kunhibava, Sherin, (2012), Islamic Banking in Malaysia, International Journal of Legal Information, Spring-Summer.

Latiff, Salma Hj Abdul, Islamic Banking in Brunei and The Future Role of Centre For Islamic Banking, Finance and Management (CIBFM), Islamic Banking and Finance Fundamentals and Contemporary Issues by Syed Ali dan Ausaf Ahmad.

Mannan, M. A., (1997), Teori dan Praktek Ekonomi Islam, terj. M. Nastngin, Yogyakarta: Dana Bhakti Wakaf.

Mardiah, Nur Hilda, (2016), Kepentingan Ekonomi Politik Singapura Dalam Menerapkan Sistem Ekonomi Islam, JOM FISIP, Vol. 3, No. 2, Oktober.

Mohammad, Muhammad Taqiuddin, et.al, (2013), The Historical Development of Modern Islamic Banking: A study in South-East Asia Country, Academic Journals, 1 November.

Muhammad, (2004), Bank Syariah, Yogyakarta: Penerbit Ekonisia.

Nugroho, Any, (2015), Hukum Perbankan Syariah, Yogyakarta: Aswaja Pressindo.

Pooprasert, Ruengrit, Chaiyasri, Anaknong, (2012), Islamic Finance in Thailand: Prospects and Challenges, IFN Islamic Finance, January.

Prasetyo, Luhur, (2010), Undang-undang Perbankan Syariah, Ponorogo: STAIN Ponorogo Press.

Rama, Ali, (2015), Analisis Deskriptif Perkembangan Perbankan Syariah Di Asia

Tenggara, The Journal of Tauhidinomics, Vol. 1, No. 2.

Sjahdeini, Sutan Remy, (2014), Perbankan Syariah Produk-Produk dan AspekAspek Hukumnya, Jakarta: Prenadamedia Group.

Sukirno, Sadono, (1996), Pengantar Teori Makroekonomi, Jakarta: Raja Grafindo Persada,.

Thani, Nik Norzul, et.al, (2010), Law and Practice of Islamic Banking and Finance, 2nded, Petaling Jaya: Sweet \& Maxwell Asia.

Umam, Khaerul, (2013), Manajemen Perbankan Syariah, Bandung: Pustaka Setia.

Venardoz, M. Angelo, (2005), Islamic Banking and Finance in South-East Asia: Its Development and Future, Singapore: World Scientific Publishing,.

Wirdyaningsih, (2005), Bank dan Asuransi Islam di Indonesia, Jakarta: Kencana Media Group.

http://documents.worldbank.org/curated/en/748841468087856489/pdf/106382WP-P153163-PUBLIC.pdf hal 4 diakses pada tanggal 17 November 2018 http://www.bnm.gov.my/guidelines/05_shariah/02_Shariah_Governance_Framew ork_20101026.pdf diakses pada tanggal 5 Januari 2019.

http://www.amanahbank.gov.ph/about-the-bank/history, diakses pada tanggal 11 November 2018

http://www.ibank.co.th/2010/en/about/about_detail.aspx?ID=1 diakses pada tanggal 11 November 2018 